\title{
Introduction: On The Beginning of Qualitative Research in Pedagogy in the Netherlands
}

\author{
Hans Bleeker, Bas Levering, and Karel Mulderij \\ University of Utrecht
}

In 1974 Ton Beekman introduced a new element in his course on phenomenology at the State University of Utrecht. Until then, the seminar had been focused on reading and explaining important texts on the subject, such as Gerd Brand's Die Lebenswelt. But from that moment on, attending Beekman's phenomenology course implied truly doing phenomenology. Students were asked to write on specific themes of their own lived experience such as "Being afraid in the dark," "To fall asleep and to awake," and first-time experiences like "My first schoolday," "My first bike," and "My first stay at another person's house"-a venture with a discernible air of subjectivity around it. What would start as an exercise in phenomenological analysis often turned into an important contribution to the knowledge of the lifeworld of children, with practical pedagogical implications. This is witnessed by a long list of titles of master's theses written under the supervision of Ton Beekman. Some of the different subjects elaborated in these theses are "Children at the Dentist," "Children at Play Outdoors," "Children, School Architecture, and the School Environment," "Children and Animals," and "Experiences of Children in Social Welfare Institutions." Several doctoral dissertations in this new methodological tradition are nearing completion.

What Ton Beekman did was not all new. He is the enthusiastic successor of the so-called Utrecht School, having studied with Langeveld, Buytendijk, and Linschoten. Some years ago, when someone dared to picture the Utrecht School as a historical phenomenon whose influence died out in the late ' $50 \mathrm{~s}$, he reacted furiously. He not only demonstrated his comprehensive knowledge of the subject, but made it clear that the Utrecht School is still very much alive. "The Utrecht School is dead! Long live the Utrecht School!" was the title of the essay in which he presented a variety of research projects which must be recognized as phenomenological in a new sense (List of 'Ton Beekman's Publications, p. 8, \#37).

But that avowed interest in doing phenomenology, as we know it from his later work, was still absent in the beginning. When in 1964 Ton Beekman graduated with a major in pedagogy and psychology (he finished his philosophical and theological studies in 1954), there was a climate of change in the social sciences in the Netherlands. 
Linschoten, one of the foremost phenomenologists, became one of the most passionate opponents of phenomenology after a visit to the United States. Another psychologist, De Groot, wrote a program in the early ' 60 s and intended to create an empirical analytical turn in the social sciences. His book Methodologie turned out to be the standard for the new orientation. This discussion on method was not new in pedagogy; the same kind of discussions took place in the '20s.

Langeveld disputed with De Groot, and later Beekman and Bijl took over Langeveld's job in fighting Brus, a pedagogue from Nijmegen who defended the empirical analytical point of view for the research of education (\#3). In 1967 they wrote a treatise together entitled Service of The Social Sciences and their Methodology (\#4), which was never published officially but appeared as a stencil. The authors presented it as a report of preliminary thoughts on the subject, but, nonetheless, it can be found cited in many official publications of other social scientists.

In 1972, Beekman completed his work on this subject with his doctoral dissertation Helpful Insight: Pedagogy as a Social Planning Science (\#10). He continued the tradition of Langeveld in stating that pedagogical theory must first of all be helpful, and the only way it can be helpful is not to concentrate on generality but insist on relevance to life (werkterreinbinding). His view on the responsibility of the social scientist is opposed to that of De Groot. De Groot takes the community of scientists to be the responsible forum, which implies a formal responsibility to a set of methodological rules. Beekman speaks of responsibility to participants, the parents and children, and the professional educators first of all, and then to fellow scientists under special conditions. He made very clear the differences that exist between a social science from a phenomenological point of view and an empirical analytical social science: science as social action thematically in contrast to science as a knowledge system, science as a planning (information) system in contrast to science as an information system.

Nowadays, other themes are discussed in theoretical pedagogy. Yet the large influence of Beekman's book can still be discovered in publications on the philosophy of science in several pedagogical subdisciplines. In orthopedagogy (special education) and here and there in educational research, one can find helpfulness and the idea of social planning science as leitmotifs with a direct reference to the work of Beekman. Beekman himself, however, seems to be rather disappointed in the adaptations of his ideas. In Dutch educational research, for instance, social democratic ideas about education fused too easily with methods of social technology. The result turned out to be a child-forgotten school system in Beekman's eyes. 
Only one year after his doctoral dissertation was published, he stated in the written version of his inaugural lecture (\#12), "Educational science as social planned science is too much inclined to look only at later, with only means-ends schemes."

Although the phenomenological voice was never silent in his work, Beekman's Helpful Insight was above all a treatise in the philosophy of science. Langeveld pointed out at the time that Beekman's work could lead to a lot of terminological change in the field of the methodology of pedagogy. From his inaugural lecture onwards, Beekman tried to keep his feet firmly on the ground and severely criticized doing social science with one's head in the clouds. "Theory of knowledge? Philosophy of science? It's easy to be wise after the event. It surely offers some gain (and so it is important enough) as therapy, as purifying method, but we never learn what has to be done" (\#12, p. 23).

Beekman is an anarchist in spirit, and if there was one philosopher of science by whose work Beekman was truly impressed, it was that of Paul Feyerabend (\#12, p. 32). Feyerabend's work was expressive of the same stance that Beekman took when he liked to call himself "an epistemological anarchist."

In "Pluriform Reality" (\#12), Beekman tackled the problem of relevance in the social sciences. Inspired by the work of Alfred Schutz, he started the analysis of the problem of relevance in the social sciences with the analysis of relevance in ordinary life. The difference between science and ordinary life is not absolute: "We only say this is science if the knowledge is more reflective, more conscious, more systematized, and more distant than the knowledge of ordinary life, therefore a gradual difference." Beekman saw theoretical and instrumental relevance as legitimate for the social sciences, if they are open and useful, because they are often neutral. But we have to see the person as an autonomous self-responsible being and that makes the emancipatory relevance the most fundamental relevancy of the social sciences, and only really in pedagogy (\#12, p. 20). The right of schools for the education of pedagogues to exist is as counselors. Advice is always dialogical. The counselor is willing to discuss (\#12, pp. 20-21).

We select, see as worthwhile, as (positively) relevant that which furthers people's own opinions on what makes life worthwhile for them. This joint principle is an "open" principle insofar as you can never say a priori how it will grow, what exactly will be the meaning of this particular human life. This principle, by the way, can only exist if we agree that no one can or is allowed to press or to persuade another person to some particular meaning of life. (\#12, p. 15) 
Meanwhile, in 1974, Beekman presented his position in two more comprehensive and introductory articles: "Place and Task of Pedagogy" (\#14) and "A Practical Anthropology" (first version, $\# 16, \# 22$, \& \#23). His belief that truth is a dialogical concept is most apparent in his later works. When speaking of "problem-assimilating force," while formulating the criterion of truth in his dissertation, he did not mean to imply a difference when later he emphasized its dialogical character. And the interest in the lifeworld of children, which became the central theme later on, is recognized as highly important in his "Pluriform Reality":

We shall have to pay very much attention to the empirical anthropology of children's way of existence. Among other things we have to elucidate the value of being a child, which can not be reduced to what it will be later on; we have to pay more attention to the value of the here and now. (\#12, p. 28)

Beekman's move to doing phenomenology can be illustrated very well if we read the introduction he wrote for the reprint of Beets' Understanding and Distinction. An Inquiry Concerning the Relationship of Medical and Pedagogical Thought (\#20). It is all there within six pages. As for the continuity in the development of Beekman's work, there is the link to the analyses of the Utrecht School of the early '50s. Beets, pupil of Langeveld and unrivaled in his concrete phenomenological descriptions, is defending the personal encounter as a research method of full value. The discontinuity in the development of Beekman's work is due to that restrained distaste for the philosophy of science. He defends Beets' subjectivity, lived experience as opposed to the claim for objectivity. He is not afraid to defend Beets' bourgeois position in those high days of the revival of Marxism; he is even proud to be bourgeois in that sense. He takes a well considered stance against macroanalysis in pedagogy.

Economic macro-analysis, for instance, has to be done by others than pedagogues. But with respect to relationships, this is what the pedagogue should be able to talk about: in an earlier stage the pedagogue should pay more attention to "relationships of power" and their possible frustrating impact on education, at least nowadays ... The diagnosticist can become an instrument of the labour system of a society, an instrument used against the interest of the child. And he can become such an instrument in spite of his best intentions. (\#20, p. 10)

The workbook for phenomenological research in education (\#23, \#34) he wrote together with his assistant Karel Mulderij as a guide for doing phenomenological research as developed in university courses. It functions also as a philosophical foundation of the research method using a nonphilosophical vocabulary. The method 
presented was strongly criticized in Dutch scientific journals because of its subjectivity and its lack of generality of results. In those days, it was not at all accepted in the Dutch university milieu to recognize qualitative research methods as research methods of equal merit. The philosophical foundation was criticized, in particular, because of lack of thoroughness. To be honest, the book is rather provocative with respect to the needlessly difficult language so commonly used in traditional phenomenological literature. But it helped many students and others to take their first step on the path of analyzing lived experience. For years the book was the only introduction in the Dutch language to qualitative methodology in pedagogy.

The research Beekman carried out during his visits to Ann Arbor deepened his dialogical methodology. Personal encounters with children is the main theme in this later work and the reason he chose the reintroduction of the child's world by the child himself: Hand in Hand With Sasha: On Participating Observation (\#32; \#41); Welt der Kinder, nur eine Spielwelt? (\#43) (Valerie Polakow, coauthor). Though qualitative research may be in vogue nowadays in the Dutch social sciences, Beekman is criticizing a lot of fainthearted attempts, because what is presented as qualitative research is in fact quantitative research in disguise. The only elements missing are the numbers. He speaks ironically of research with Spradley-like characteristics. He is convinced that the idea of "grounded theory" of Glaser and Strauss, for example, is a consequence of a form of naive realism. The world is always the world of subjects. The world is never something in itself. So it may be that, as the interest for qualitative research has grown tremendously in the last few years, most of the researchers speak a different language than Beekman does. They do not follow him to leave the pursuit of "generality" in practical situations, but they stick spasmodically to that old scientific ideal. They remain afraid to "go native" and are not capable of giving themselves up to the forces of the field. He is still ahead. We hope we can keep up with him.

We are proud to be able to present to Ton Beekman a collection of articles on the topic "Phenomenology and Ordinary Life" on the occasion of his retirement as a professor in pedagogy and its methodology at the University of Utrecht. It was not at all difficult to find eight outstanding phenomenologists ready to participate in an international Liber Amicorum. And a true Liber Amicorum it is, because they did not limit their participation to the delivery of a personal contribution on the elaboration of the theme "Phenomenology and Ordinary Life." All of them show, by treating an issue central to his work, that they have been inspired by the work of Ton Beekman. 


\section{List of Publications by Prof. Dr. A.J. Beekman}

1. (1961). Youth and religion in a changing world. Social Compass, Review of Socio-Religious Studies, 8, 447-468.

2. (1964). Het seminarie, een tegenwoordig-verleden tijd? (pp. 72-85). In Priesterroeping en seminarie. Haarlem.

3. (1966). Antwoord aan drs. Brus. Opvoeding, Onderwijs en Gezondheidszorg, 17, 282-288. (Samen met J. Bijl)

4. (1967). De dienstverlening der sociale wetenschappen en hun methodologie; de opvoedkunde een sociale planwetenschap. Utrecht: Gestencilde uitgave. (als apart deel: Aantekeningen bij de dienstverlening....) (Samen met J. Bijl)

5. (1968). Marcuse, profeet van de revolutie der studenten. Blauwdruk, 9, 21-34.

6. (1969). Paedagogiek, een diskussie-bijdrage. Mededelingenblad N.V.O., 5, 12-14.

7. (1969). Kort bestek van een pleidooi. Mededelingenblad N.V.O., 5, 92-95.

8. (1970). Stellingen omtrent opvoedingswetenschap en maatschappijkritiek, Mededelingenblad N.V.O., 6, 15-19.

9. (1971). De betekenis van Langeveld. Pedagogische Studiën, 48, 518-527.

10. (1972). Dienstbaar inzicht, opvoedingswetenschap als sociale planwetenschap, Groningen: Wolters-Noordhoff (proefschrift).

11. (1972). Een pleidooi voor "Freiräume." Pedagogische Studien, 49, 387-388.

12. (1972). Zekerheid en twijfel in de opvoedingswetenschap. In Th. G. Bolleman (Red.), Pedagogiek in Ontwikkeling (pp. 23-34). Tilburg: Zwijsen.

13. (1973). Veelvormige werkelijkheid, een beschouwing over het relevantie-probleem in de sociale wetenschap, meer in het bijzonder in de opvoedingswetenschap. Meppel: Boom.

14. (1973). Plaats en taak van de opvoedingswetenschap. In T. Tak (Red.), Moed tot zelfstandigheid (pp. 25-35). Meppel: Boom.

15. (1973). Dienstbaar inzicht (2e Druk). Zie n. 10.

16. $(1973,1974)$. Oordelen over de waarde van het menselijk bestaan: Over de mogelijkheden van een empirische pedagogische anthropologie. Wijsgerig Perspectief, 14(1), 11-23. 
17. (1974). Theoretische pedagogiek, bestaat dat nog? Pedagogische Forum, 8(8), 281-293.

18. (1975). Dienstbaar inzicht (3e Druk, met Nawoord). (Zie 10).

19. (1975). Een opvoedingstaak. De Lichamelijke Opvoeding, 63(1), 4-9.

20. (1952, 1975). Inleiding in heruitgave van N. Beets: Verstandhouding en onderscheid. Meppel: Boom.

21. (1976). Professor Fokkema is verontrust. Pedagogische Studiën, 53, 172-174.

22. (1976). Een praktische anthropologie. Pedagogische Tijdschrift, 1(8), 429-451.

23. (1977). Beleving en ervaring, werkboek fenomenologie voor de sociale wetenschappen. Meppel: Boom. (Samen met K.J. Mulderij)

24. (1977). Een praktische anthropologie. In B. Spiecker, (Red.), Meedoen en zeker weten (pp. 9-49). Meppel: Boom.

25. (1978). Wie niet weg is wordt gezien, ik kom! Over de betekenis van verstoppertje spelen in het kinderleven en de konsekwenties daarvan voor de woonomgeving. Jeugd en Samenleving, 8(8), 468-486. (Samen met H. Bleeker en K.J. Mulderij)

26. (1978). Hide ' $n$ ' seek, the world through children's eyes. Utrechtse Pedagogische Verhandelingen, 1(1), 2-23. (Samen met L. Barritt, H. Bleeker, en K.J. Mulderij)

27. (1979). Meaningful educational research, chap 5. Utrechtse Pedagogische Verhandelingen, 2(2), 24-51. (Samen met L. Barritt, H. Bleeker, en K.J. Mulderij)

28. (1979). Opkomst en neergang van de kinderwereld: Een historische illusie? Utrechtse Pedagogische Verhandelingen, $2(3), 43-56$.

29. (1980). Mijn rug had een warm-water-theorie. Een voorstel tot inperking van het gebruik van de term theorie. $A-80,1(1), 16-17$.

30. (1982). Hide-and-seek and peekaboo: The world through children's eyes. Outlook, 44, 34-51. (Samen met L. Barritt, H. Bleeker, en K.J. Mulderij).

31. (1982). Das Versteck-Dich-Spiel. In W. Lippitz, \& K. MeyerDrawe (Eds.), Lernen und seine Horizonte, phänomenologische Konzeptionen (pp. 84-107). Königstein Ts. Scriptor. (Samen met L. Barritt, H. Bleeker, K.J. Mulderij, en K.O.K.Schmitt)

32. (1982). Science as a dialogue with children: Aan de hand van Sasha (I), over vuurvliegjes, Grandma Millie en enkele andere ruimteverhalen met een aanhangsel (II) over deelnemende ervaring. Tekst SISWO-bijeenkomst. Amsterdam: SISWO. 
33. (1982). Hoe kunnen feiten normen worden: In gesprek met Bas Levering. Utrechtse Pedagogische Verhandelingen, 5(2/3), 191-202.

34. (1983). A handbook for phenomenological research in education. School of Education, University of Michigan. (With L. Barritt, H. Bleeker, \& K. Mulderij)

35. (1983). Human science as a dialogue with children. Phenomenology + Pedagogy, 1(1), 374-376.

36. (1983). Een realistische of een rationalistische kenleer. Pedagogische Studiën, 6, 374-376.

37. (1983). De Utrechtse School is dood! Leve de Utrechtse School! Pedagogische Verhandelingen, 6(1), 61-70.

38. (1983). Gaat de rede boven de zede, of de zede boven de rede? Pedagogische Verhandelingen, 6(2/3), 12-14.

39. (1983). The erosion of childhood. Phenomenology + Pedagogy 1(1), 103-105. (Book review)

40. (1984). Les sciences humaines: Un dialogue avec l'enfance. $L a$ Revue Canadienne de Psycho-Education, 13(1), 25-32.

41. (1984). Hand in hand mit Sasha; Teilnehmende Erfahrung. In W. Lippitz \& K. Meyer-Drawe (Eds.), Kind und Welt (pp. 11-26). Königstein/ts: Forum Academicum.

42. (1984). De onderwijzer zij opvoeder, deskundig, met een hart en zonder code. Pedagogisch Tijdschrift, 9, 237-239.

43. (1984). Welt der Kinder, eine Spielwelt? In H. Danner \& W. Lippitz (Eds.), Beschreiben, verstehen, handeln (pp. 69-80). München: Röttger Verlag. (Samen met V. Polakow)

44. (1984). Het kritisch vermogen van een fenomenologische aanpak. Utrechtse Pedagogische Cahiers, 6, 106-115.

45. (1984). A phenomenological tradition in Holland. Paper presented at the AERA Congress, New Orleans.

46. (1984). Cache-cache et coucou ou le monde vue par les enfants. La Revue Canadienne de Psycho-Education, 13(2), 145-156. (Samen met L. Baritt, H. Bleeker, en K.J. Mulderij)

47. (1985). Das kritische Potential phänomenologisch orientierter Pädagogik. In W. Lippitz \& A.J. Beekman (Red.), Utrechtse Pedagogische Cahiers, 7, 109-123.

48. (1985). Kinder wohnen auch, eine Orientierung in die Niederländische Kinderlandschaft. In H. Hengst (Red.), Kindheit in Europa. Zwischen Spielplatz und Computer (pp. 247-279). Frankfurt: Suhrkamp. (Samen met H. Bleeker en K.J. Mulderij)

49. (1985). Researching educational practice. North Dakota: University of North Dakota Press. (With L. Barritt, H. Bleeker, \& K.J. Mulderij) 
50. (1985). Bruikbaar onderzoek nader bezien. Pedagogische Verhandelingen, 7(1), 47-58.

51. (1985). Structures of responsibility in the pedagogical relation. 4th International Human Science Research Conference, University of Alberta. 


\section{Curriculum Vitae: Prof. Dr. A.J. Beekman}

1929

Born in The Hague, the Netherlands.

1947

Graduated from gymnasium $\alpha$ (classical) at The Hague.

1947-1954

Philosophical and theological studies (Roman Catholicism).

$1955-1957$

High school teacher, classics.

1957-1964

Studied educational and clinical psychology at the Rijksuniversiteit, Utrecht;

Social Work at Youth Center Utrecht-West.

January 1960-July 1960

Summer term at the University of Hamburg (Erziehungsberatung).

October 1963-April 1964

Traveled in the United States (together with the late drs. $O$. Thomasse ) doing research in counseling in senior high school and junior college.

June 29, 1964

Doctoral examination cum laude (education, clinical psychology, psychopathology).

March 1964-October 1965

Researcher at Hoogveld Instituut.

November $1965-1986$

Member of the staff of Pedagogisch Instituut Rijksuniversiteit Utrecht.

February 4, 1972

Doctorate in social sciences (promoter: M.J. Langeveld), confer no. 10 list of publications.

January 1980

Professor in educational theory and methodology of educational research;

Chairman of the department (Pedagogisch Instituut Rijksuniversiteit Utrecht). 
1976, 1977, and 1979

Invited for lectures to the University of Michigan, Ann Arbor; in 1979 to Duquesne University, Pittsburgh; in 1982 and 1983 to the University of Alberta, Edmonton.

1981-1982

Dutch professor in residence at the University of Michigan (School of Education). 